\title{
Produção de hidrolisados protéicos de penas de frango utilizando bactérias queratinolíticas ${ }^{*}$
}

\author{
JAQUELINE LESSA MACIEL
}

Adriano Brandelli (Orientador - UFRGS)

Banca: Eduardo Cezar Tondo (UFRGS), Carlos Tadeu Pippi Salle (UFRGS), Erna Vogp de Jong (UFRGS)

Com o crescimento populacional, a indústria avícola tem se desenvolvido rapidamente, devido à demanda de alimentos. O seu produto possui grande aceitação no mercado mundial, em função do seu valor nutricional e por não existirem restrições culturais. Entretanto, este alimento gera grande quantidade de resíduos, dentre eles, as penas. Elas são compostas principalmente por queratina, substância de difícil degradação. Neste trabalho foram utilizadas duas bactérias queratinolíticas de resíduos da indústria avícola, para se avaliar a capacidade de degradação das mesmas. Foram produzidos hidrolisados de penas por proteólise bacteriana com ambos microrganismos: Bacillus cereus (KR16) e Chryseobacterium sp. (KR6). O crescimento das bactérias em diferentes quantidades de penas, e o fator de degradação das penas comprovaram que em até $5 \%$ obteve-se degradação para KR6, enquanto, para a KR16, obteve-se degradação até 1\%. A digestibilidade in vitro dos hidrolisados foi avaliada. Observou-se que o hidrolisado da bactéria KR6 apresentou maior digestibilidade, enquanto o de farinha de penas apresentou o menor valor. A composição de aminoácidos dos hidrolisados foi determinada, sendo observadas baixas concentrações de metionina, histidina e lisina. A partir da digestibilidade in vitro e da composição de aminoácidos, foram calculados o escore de aminoácidos corrigidos (PDCAAs), o coeficiente de eficiência protéica (PER) e o valor biológico (BV). O tratamento das penas com KR6 resultou em hidrolisados com os valores mais altos de PDCAAs, PER e BV, sugerindo que este microrganismo produz hidrolisados com propriedades nutricionais superiores aos demais.

Descritores: bactérias queratinolíticas, penas, hidrolisados, digestibilidade. 


\title{
Production of proteics hydrolysates of poultry feathers by keratinolitics bacterium ${ }^{* *}$
}

\author{
JAQUELINE LESSA MACIEL
}

\author{
Adriano Brandelli (Adviser - UFRGS)
}

Committee: Eduardo Cezar Tondo (UFRGS), Carlos Tadeu Pippi Salle (UFRGS), Erna Vogp de Jong (UFRGS).

The population increase promoved the increase in food demand, resulting in a very quickly poultry industry to development. Poultry meat is largely accepted in the world market because its nutritional value as well as the lack of cultural restriction. Nevertheless, this kind of food produces a great amount of residues, the feathers, which are essentially composed of keratin, a substance of difficult degradation. In this study two keratinolitic bacteria of poultry industry residues, were used in order to estimate their degradation capacity. Hydrolysed feathers were produced by bacterial proteolysis with both microorganisms: Bacillus cereus (KR16) and Chryseobacterium sp. (KR6). The development of bacteria in different feather amounts and the feather degradation factor confirmed that up to 5\% degradation was obtained to KR6 and 1\% to KR16. The digestibility in vitro, of hydrolysates was valued. The hydrolysed of the bacterium KR6 presented greater digestibility whereas feather meal presented the lowest value. The amino acid composition of the hydrolysates was determined, and presented low concentration of methionine, histidine and lysine. In the digestibility in vitro, and the composition of the amino acids, was calculated the corrected aminoacids scoring (PDCAAs), the protein efficiency ratio (PER) and the biologic Value (BV). The feathers treated with KR6 resulted in hydrolysates with the highest values for PDCAAs, PER an BV, Suggesting that this microorganism produces hydrolysates with greater nutritional properties in relation to the others.

Key words: keratinolitic bacteria, feathers, hydrolysates, digestibility. 